\title{
PENGARUH HARGA DAN KUALITAS BERAS MERAH TERHADAP KEPUASAN KONSUMEN (Studi KAasus di CV. PURE Cianjur)
}

\author{
Oleh: \\ Ahmad Nur Rizal*) \\ Asep Saepul Alam*) \\ Fira Wahyuni**)
}

\begin{abstract}
Abstrak
Beras merah merupakan beras khusus untuk kesehatan karena memiliki sejuta manfaat yang baik bagi kesehatan tubuh manusia, namun konsumen beras merah relative sedikit dibandingkan dengan beras lainnya sehingga harga beras merah lebih tinggi atau mahal. Harga dan kualitas harus senantiasa diperhatikan dalam suatu usaha, sehingga konsumen bersedia membeli dan usaha yang di lakukan mendapat keuntungan serta bisa mendapatkan pelanggan yang tetap. Penelitian ini di lakukan di CV. Pure Cianjur dari bulan November 2019 sampai Agustus 2020 dengan tujuan 1). Mengetahui apakah harga secara parsial berpengaruh terhadap kepuasan konsumen, 2). Mengetahui apakah kualitas secara parsial berpengaruh terhadap kepuasan konsumen, 3). Mengkaji apakah harga dan kualitas beras merah secara simultan berpengaruh terhadap kepuasan konsumen. Penelitian ini dilakukan pada 70 responden yang mengkonsumsi beras merah dengan menggunakan metode analisis regresi linier berganda. Hasil penelitian ini menunjukan bahwa nilai regresi variabel harga ditunjukan dengan nilai $\mathrm{t}$ hitung $>\mathrm{t}$ table yaitu $2.698>1.996$ dengan nilai signifikansi $0,009<0,05$ yang artinya $\mathrm{H} 1$ diterima dan $\mathrm{H} 0$ ditolak. Sedangkan besarnya nilai regresi variabel kualitas ditunjukan dengan dengan nilai t hitung $>$ dari $\mathrm{t}$ tabel $3.357>1.996$ dengan nilai signifikansi $0,001<0,05$ yang artinya $\mathrm{H} 1$ diterima dan $\mathrm{H} 0$ ditolak. Secara simultan variabel harga dan kualitas memiliki pengaruh yang signifikan terhadap kepuasan konsumen, dengan nilai signifikansi $0,000<0,05$ yang artinya $\mathrm{H} 1$ diterima dan $\mathrm{H} 0$ ditolak.
\end{abstract}

Kata kunci : Beras merah, Harga dan kualitas, Kepuasan konsumen.

\section{Abstract}

Brown rice is special rice for health because it has a million good benefits for the health of the buman body, but brown rice consumers are relatively few compared to other rice so that the price of brown rice is bigher or expensive. Price and quality must always be considered in a business, so that consumers are willing to buy and the business is being done to benefit and can get regular customers. This research was conducted at CV. Pure Cianjur from November 2019 to August 2020 with the aim of 1). Knowing whether the price partially affects customer satisfaction, 2). Knowing whether quality partially affects customer satisfaction, 3). Assess whether the price and quality of brown rice simultaneously affect customer satisfaction. This research was conducted on 70 respondents who consumed brown rice using multiple linear regression analysis method. The results of this study indicate that the regression value of the price variable is indicated by the value of $t$ count $>t$ table, namely 2,698 > 1,996 with a significance value of $0.009<0.05$, which means that H1 is accepted and $\mathrm{HO}$ is rejected. Meanwhile, the regression value of the quality variable is indicated by the value of $t$ count $>t$ table of $3.357>1.996$ with a significance value of $0.001<0.05$, which means that H1 is accepted and HO is rejected. Simultaneously the price and quality variables have a significant effect on customer satisfaction, with a significance value of $0.000<0.05$, which means that $\mathrm{H} 1$ is accepted and $\mathrm{HO}$ is rejected.

Keywords: Brown rice, Price and quality, Customer satisfaction.

*) Dosen Fakultas Sains Terapan UNSUR.

**) Alumni Fakultas Sains Terapan UNSUR.

PENGARUH HARGA DAN KUALITAS BERAS 


\section{PENDAHULUAN}

Sektor pertanian merupakan sektor yang mempunyai peranan penting dalam mengembangkan perekonomian Indonesia, karena Indonesia merupakan salah satu negara yang memiliki hasil pertanian yang sangat melimpah dan Indonesia merupakan salah satu negara yang dimana sebagian besar pendapatannya di dapatkan dari hasil pertanian. Masyarakat Indonesia adalah pengkonsumsi beras terbesar di dunia, hal ini dibuktikan dengan adanya tingkat konsumsi sebesar 139,5 kg/orang (BPS, 2012).

Beras merupakan salah satu produk pangan yang paling banyak dikonsumsi oleh masyarakat Indonesia, dan kini beras menjadi produk pangan yang sangat penting untuk dikonsumsi oleh masyarakat karena kebanyakan orang Indonesia mengkonsumsi beras sebagai bahan pokok utama makanan tetapi ada juga sebagian orang yang mengkonsumsi beras merah melainkan untuk memenuhi kebutuhan tubuh atau digunakan untuk kesehatan.

Beras merah merupakan beras yang memiliki pigmen warna merah yang dipercaya baik untuk kesehatan tubuh. Beras merah ini mempunyai kandungan gizi yang jauh lebih baik dibanding beras putih. Beras merah sering digunakan sebagai menu diet sehat untuk menurunkan berat badan serta bagi penderita diabetes. Beras merah biasa di makan seperti nasi putih yang umumnya dikonsumsi orang Indonesia.

Salah satu Kabupaten yang memiliki hasil pertanian yaitu Kabupaten Cianjur yang dikenal sebagai penghasil beras unggulan. Kabupaten Cianjur merupakan daerah yang mempunyai hasil produksi beras yang telah memberikan kontribusi dan pelayanan dalam penyediaan pangan dengan memiliki komoditas unggul lokal yaitu beras merah Cianjur. Beras merah Cianjur merupakan beras khas Cianjur yang memiliki citarasa yang khas enak pulen dan memiliki wangi aroma yang menyengat, rasa khas tersebutlah yang dihasilkan dari beras merah Cianjur.

CV. Pure Cianjur adalah sebuah badan usaha yang memasarkan beberapa beras varietas unggul salah satunya adalah beras merah. Berdasarkan hasil observasi, CV. Pure Cianjur telah memasarkan produknya ke beberapa daerah diluar Kota Cianjur, seperti : Bandung, Bogor, Jakarta dan Karawang. Dengan begitu, beras yang dipasarkan oleh CV. Pure Cianjur khususnya beras merah semakin dikenal oleh masyarakat luas. CV. Pure Cianjur membangun komunikasi melalui media komunikasi pemasaran dimana perusahaan berharap dengan strategi yang digunakannya tersebut dapat menciptakan hubungan komunikasi yang efektif dalam rangka mempromosikan produk kepada konsumen.

Secara umum, kondisi padi beras merah di Indonesia telah dijelaskan oleh Badan Penelitian dan Pengembangan Pertanian (2005) bahwa di Indonesia padi yang berasnya berwarna merah kurang mendapatkan perhatian dibandingkan dengan padi beras putih padahal beras merah mengandung gizi tinggi, bahkan banyak produk makanan bayi yang beredar di pasar beberapa diantaranya menggunakan beras merah sebagai bahan baku utamanya. Bahkan ada produk makanan sehat yang bahan bakunya 100\% dari tepung beras merah. Di Indonesia belum tersedia varietas unggul padi beras merah kecuali varietas Bajbutong yang dilepas tahun 1985 dan itu pun tidak meluas pengembangannya. Oleh karena itu, beras merah yang diperdagangkan di berbagai daerah diduga berasal dari impor atau dari padi gogo lokal yang umumnya berdaya hasil rendah dan berumur dalam.

Beras merah selain kurang mendapatkan perhatian dari pemerintah beras merah juga produksinya sedikit dan terbatas harganya pun lebih mahal dan sulit untuk didapatkan. Selain itu juga, beras merah lebih cepat rusak karena tidak memiliki ketahanan simpan yang tinggi dibandingkan dengan beras lainnya, dengan demikian produsen harus senantiasa memperhatikan produk beras 
yang berkualitas untuk mendapatkan kepuasan setelah mengkonsumsi produk beras merah tersebut.

Kepuasan konsumen adalah perasaan positif konsumen yang berhubungan dengan produk/jasa selama menggunakan atau setelah menggunakan jasa atau produk (Bachtiar,2011). Konsumen memberikan respon tertentu sebagai hasil evaluasinya terhadap kesenjangan antara harapannya dengan kinerja produk (Tse \& Wilton dalam Gisel dan Cote, 2000). Meningkatkan kepuasan konsumen dengan meningkatkan nilai konsumen merupakan fokus utama bagi setiap perusahaan.

Tujuan penelitian ini adalah untuk : Mengetahui pengaruh harga secara parsial terhadap kepuasan konsumen. 2) Mengetahui pengaruh kualitas secara parsial terhadap kepuasan konsumen. 3) Mengkaji apakah harga dan kualitas beras merah secara simultan berpengaruh terhadap kepuasan konsumen.

\section{METODE PENELITIAN}

Penelitian ini dilaksanakan di CV. Pure Cianjur. Hal ini dilakukan karena CV.Pure Cianjur merupakan salah satu perusahaan yang ada di Kabupaten Cianjur yang sudah memasarkan produk beras merah ke berbagai daerah misalnya Bandung, Jakarta, Bogor dan Karawang.

Populasi dalam penelitian ini adalah konsumen yang sudah mengkonsumsi beras merah dengan jumlah responden 70 orang. Teknik sampling yang digunakan adalah non probability dan sampling kuota. Variabel penelitian meliputi dua variabel bebas (exogen) dan satu variabel tergantung ( endogen). Variabel exsogen terdiri dari Harga (X1), Kualitas (X2), sedangkan variabel endogennya Kepuasan Konsumen (Y). rincian dari variabelvariabel tersebut terdapat pada table 1. Mengenai operasionalisasi variabel penelitian.

Tabel 1. Operasional Variabel.

\begin{tabular}{|c|c|c|c|}
\hline $\begin{array}{c}\text { Atribut } \\
\text { Variabel }\end{array}$ & Konsep Variabel & Indikator & Skala \\
\hline $\begin{array}{l}\text { Harga } \\
\text { Beras } \\
\text { Merah } \\
(\mathrm{X} 1)\end{array}$ & $\begin{array}{l}\text { Harga seringkali digunakan sebagai } \\
\text { indicator nilai bilamana harga tersebut } \\
\text { dihubungkan dengan manfaat yang } \\
\text { dirasakan atas suatu barang atau jasa. harga } \\
\text { bersifat fleksibel sehingga nantinya } \\
\text { konsumen akan mendapatkan potongan } \\
\text { harga diwaktu tertentu Tingkat harga } \\
\text { tertentu, bila manfaat yang dirasakan } \\
\text { konsumen meningkat, maka nilainya akan } \\
\text { meningkat pula (Tjiptono, 2008; Fure, } \\
2013 \text { dalam Anwar, 2015) }\end{array}$ & $\begin{array}{l}\text { 1. Harga sesuai dengan input dan } \\
\text { output } \\
\text { 2. Harga yang ditetapkan } \\
\text { terjangkau oleh konsumen } \\
\text { 3. Harga bersifat fleksibel } \\
\text { 4. Terdapat potongan harga } \\
\text { (discount) }\end{array}$ & Likert \\
\hline $\begin{array}{l}\text { Kualitas } \\
\text { Beras } \\
\text { Merah } \\
\text { (X2) }\end{array}$ & $\begin{array}{l}\text { Kualitas beras yang diperdagangkan secara } \\
\text { objektif lebih ditentukan oleh sifat fisik } \\
\text { dan tampilan butir beras. Beras yang } \\
\text { bermutu baik memiliki harga yang lebih } \\
\text { tinggi dibandingkan dengan yang bermutu } \\
\text { biasa (Santika dan Rozakurniati, 2010; } \\
\text { International Rice Reseach Intitute IRRI, } \\
2013\end{array}$ & $\begin{array}{l}\text { 1. Aroma beras merah yang khas } \\
\text { 2. Warna beras merah harus } \\
\text { berwarna merah terang } \\
\text { 3. Kandungan Gizi yang dimiliki } \\
\text { beras merah cukup besar } \\
\text { 4. Bentuk beras merah yang utuh } \\
\text { 5. Tekstur beras Merah }\end{array}$ & Likert \\
\hline $\begin{array}{l}\text { Kepuasan } \\
\text { Konsume } \\
\mathrm{n}(\mathrm{Y})\end{array}$ & $\begin{array}{l}\text { Kepuasan konsumen merupakan perasaan } \\
\text { positif konsumen yang berhubungan } \\
\text { dengan produk/jasa selama menggunakan } \\
\text { atau setelah menggunakan jasa atau produk } \\
\text { dan } \\
\text { Konsumen akan merasa puas apabila beras } \\
\text { merah yang ditawarkan sesuai dengan } \\
\text { harapan yang diinginkan konsumen, serta } \\
\text { ketersediaan beras harus optimal. }\end{array}$ & $\begin{array}{l}\text { 1. Kesesuaian Harapan } \\
\text { 2. Kesedian Beras } \\
\text { 3. Keputusan terhadap harga yang } \\
\text { diberikan } \\
\text { 4. Keputusan terhadap kualitas } \\
\text { produk yang tersedia }\end{array}$ & Likert \\
\hline
\end{tabular}


Untuk mengetahui pengaruh parsial maupun simultan dari variabel bebas terhadap variabel tergantungnya, dilakukan analisis regresi berganda. Sebelumnya, data yang diolah merupakan data lapang yang sudah diuji validitas dan reliabilitasnya sehingga layak untuk diolah lanjut.

\section{HASIL PENELITIAN DAN PEMBAHASAN}

\section{Gambaran Umum Tempat Penelitian Sejarah dan Profil CV Pure Cianjur}

CV. Pure Cianjur diketuai oleh Ibu Siti Chodijah Ma'sum SP dengan Sekretaris Empat Kurniawati, A.MD dan Bendahara yaitu Sarah Siti Sumaerah. CV. Pure Cianjur telah terdaftar sebagai perusahaan dengan nomor 10.06.3.51.02868 yang diperoleh dari badan pelayanan perizinan terpatu dan penanaman modal Kabupaten Cianjur. CV. Pure Cianjur berlokasi di Perumahan Gading Asri, Jln. Cendana Blok nomor 31, RT/RW 01/17 Desa Bojong Kecamatan Karangtengah Kabupaten Cianjur. Lokasi tersebut terletak di rumah Ibu Siti Chodijah Ma'sum SP. CV. Pure Cianjur buka setiap hari Senin sampai Minggu kecuali libur nasional, mulai dari pukul 08.00 WIB sampai dengan pukul 16.00 WIB. CV. Pure Cianjur yang awalnya bernama Beras Cianjur "BERASKU" Pure Cianjur didirikan oleh ibu Siti Chodijah Ma'sum, SP selaku ketua pada tanggal 04 September 2014 yang sudah dirintis sejak 04 September 2011. Pada tanggal 15 Februari 2016, unit usaha ini telah berbadan hukum menjadi perseroan komanditer (CV) menjadi CV. Pure Cianjur.

Berawal terbentuknya CV. Pure Cianjur ketika ibu Siti Chodijah sebagai penyuluh pertanian yang membina Kelompok Tani Bangkit untuk meningkatkan produktivitas padi pandanwangi yang menjadi salah satu kearifan local Cianjur. Pada saat itu, dinas Pertanian Kabupaten Cianjur tempat Ibu Siti Chodijah bekerja hanya membina untuk meningkatkan produksi padi pandanwangi saja. Sehingga para Petani Kelompok Tani Bangkit kebingungan dengan pemasaran padi dan beras pandawangi yang telah dihasilkan, pada Tahun 2011 ibu Siti Chodijah mulai membantu pemasaran beras pandanwangi. Beras produk hasil dari Kelompok Tani Bangkit mulai dipasarkan oleh Ibu Siti Chodijah melalui pameran-pameran dan bazar-bazar yang diikutinya. Pemasaran pun didukung oleh pihak Dinas Pertanian dan Tanaman Pangan Kabupaten Cianjur. Beras Pandanwangi tersebut mulai dipasarkan dengan nama "Beras Cianjur" Berasku".

Pada Tahun 2014 di salah satu pameran yang diadakan di Gedung Sate Bandung, produk Beras Cianjur "Berasku" menarik minat dan dilirik serta diberikan penawaran untuk dijual diperusahaan ritel Carrefour untuk wilayah Jawa Barat. Penawaran tersebut merupakan sebuah kesempatan awal bagi perkembangan CV.Pure Cianjur.

Hingga saat ini CV. Pure Cianjur telah mengalami banyak pengembangan usaha. Mulai dari segi produk, kepemilikan asset, tenga kerja, system jual beli beras dan lain-lain. Salah satu pengembangan yang telah dilakukan oleh $\mathrm{CV}$. Pure Cianjur dengan memiliki berbagai Sertifikat PIRT dengan nomor 2153203011083-19, sertifikat halal, Sertifikat Organic dan Sertifikat Indikasi Geodrafis (SIG) untuk meningkatkan daya saing beras pandanwangi Cianjur yang mengalami penururnan output karena marak nya pengopolsan dan pemakaian pewangi yang telah beredar di pasaran.

\section{Visi dan Misi CV. Pure Cianjur Visi}

Mengembangkan, memasarkan dan mewujudkan produk unggulan beras khas Cianjur sebagai beras khusus dan premium berkualitas terbaik dan berdaya saing

Misi

1. Mengembangkan dan memasarkan produk unggulan beras khas Cianjur dan produk Cianjur lainnya. 
2. Menjalin kemitraan dengan kelompok tani padi organic yang menerapkan system pertanian organic

3. Memberdayakan petani dan keluarga petani melalui peningkatan sikap, pengetahuan dan keterampilan petani, khususnya petani padi

4. Memposisikan petani sebagai penentu harga komoditas yang dihasilkan

5. Menciptakan lapangan pekerjaan di lingkungan usaha CV. Pure Cianjur.

\section{Struktur Organisasi CV. Pure}

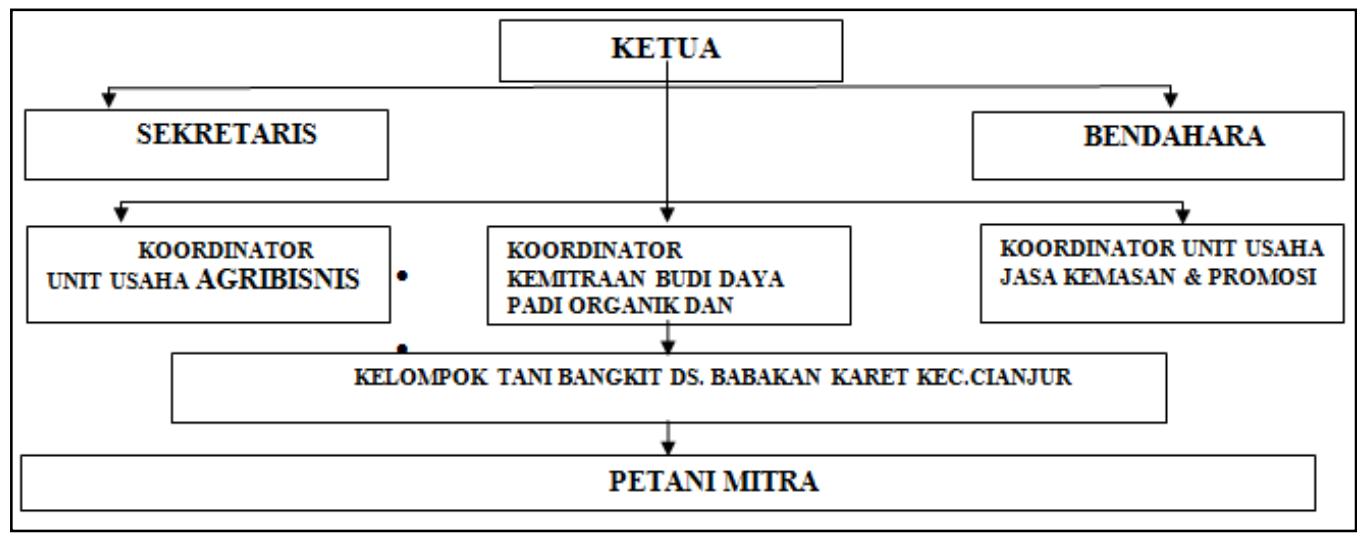

Gambar. 1 Struktur organisasi Cv. Pure.

\section{Karakteristik Responden}

Responden dalam penelitian ini berjumlah 70 orang. Responden merupakan konsumen beras merah yang terus menerus atau yang mengkonsumsi beras merah minimal 3 kali. Hal ini dilakukan agar responden yang digunakan mencerminkan konsumen yang sesungguhnya, sehingga dapat merepresentasikan hasil yang diteliti.
Penelitian ini meliputi jenis kelamin, usia, pendidikan, dan pendapatan.

\section{Karakteristik Responden Berdasarkan Jenis Kelamin}

Berdasarkan jenis kelamin, responden dibedakan menjadi laki-laki dan perempuan. Hasil analisis karakteristik responden berdasarkan jenis kelamin ditunjukkan seperti yang tercantum pada gambar 2 :

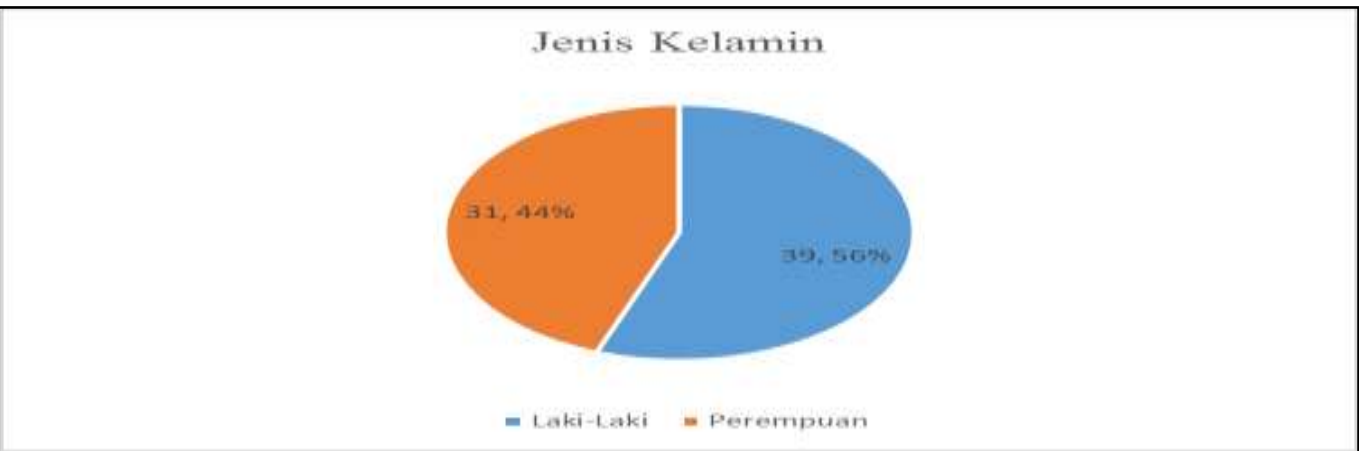

Gambar 2. Karakteristik responden berdasarkan jenis kelamin. Sumber : Data Primer, 2020.

Berdasarkan pada gambar di atas dapat dilihat bahwa sebagian besar konsumen yang membeli beras merah dari 70 responden berjenis kelamin perempuan sebanyak 31 orang atau sebesar $44 \%$ sedangkan responden berjenis kelamin laki-laki sebanyak 39 orang atau 56\%. Maka dapat diketahui bahwa konsumen yang paling banyak membeli beras berjenis kelamin laki-laki. 


\section{Karakteristik Responden Berdasarkan Usia \\ Berdasarkan usia, responden dalam} penelitian ini dibedakan menjadi usia 18-
25 tahun, usia 26-35 tahun, dan usia $>35$ tahun. Hasil analisis responden berdasarkan usia dapat dilihat pada gambar 3:

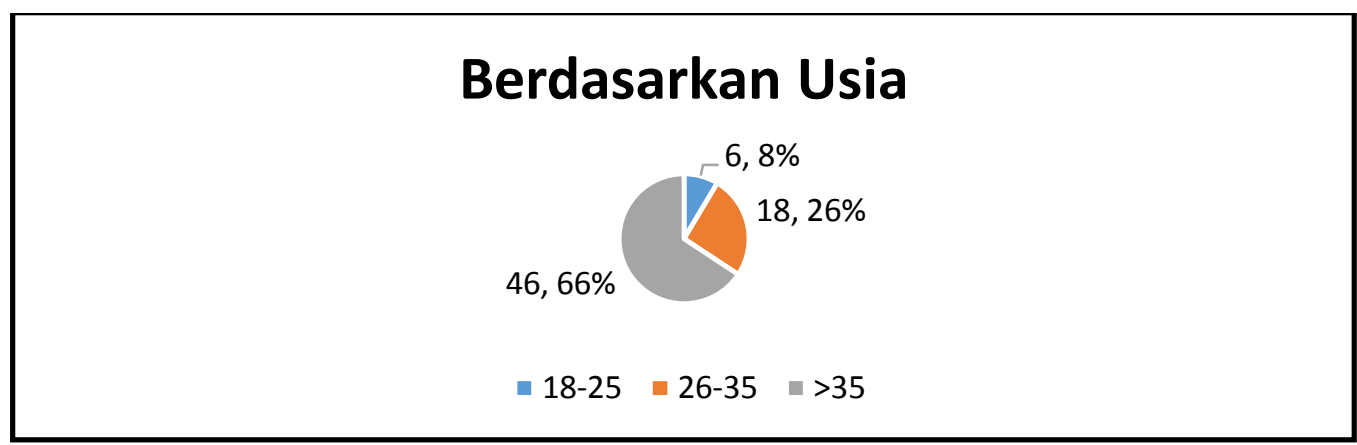

Gambar 3. Karakteristik Responden Berdasarkan Usia.

Sumber : Data Primer (2020).

Berdasarkan pada gambar di atas dapat dilihat bahwa sebagian besar konsumen yang membeli beras dari 70 responden berdasarkan usia 18-25 tahun sebanyak 6 orang atau sebesar $8 \%$, pada usia 26-35 tahun sebanyak 18 orang atau sebesar 26\% dan pada usia $>35$ tahun sebanyak 46 orang atau sebesar $66 \%$. Peneliti menyimpulkan bahwa beras merah banyak diminati oleh konsumen yang berusia $>35$ tahun. Karena mereka usia yang sudah dikatakan tua jadi mereka mengkonsumsi beras merah untuk kebutuhan tubuh untuk kesehatan.

\section{Karakteristik Responden Berdasarkan Tingkat Pendidikan}

Berdasarkan tingkat pendidikan, reponden dalam penelitian ini dibedakan menjadi SD sederajat, SMP, SMA dan S1 (Perguruan Tinggi). Hasil analisis karakteristik responden berdasarkan tingkat pendidikan dapat dilihat pada gambar 4 :

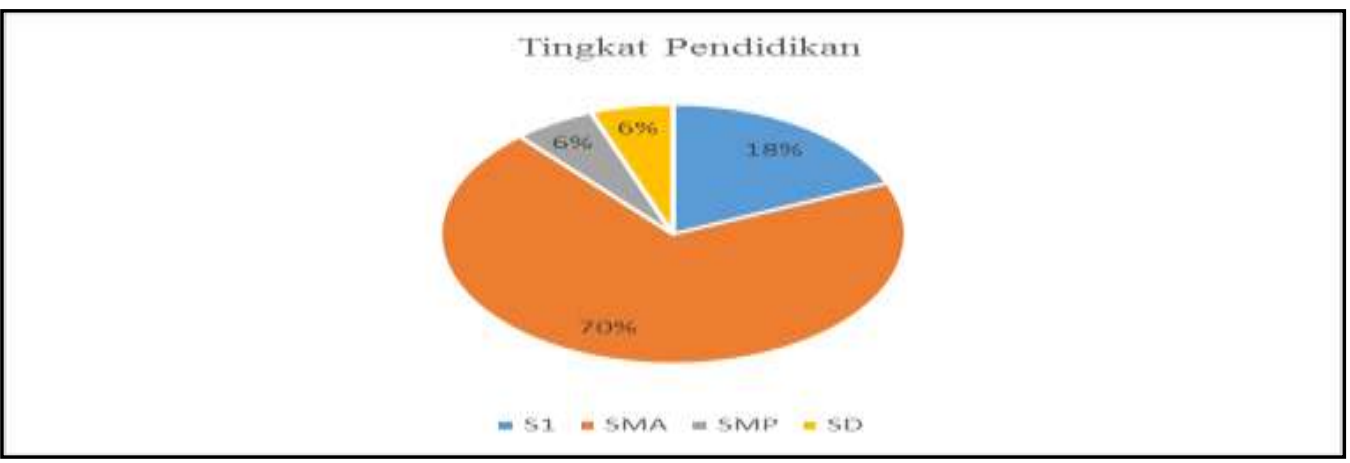

Gambar 4. Karakteristik Responden Berdasarkan Tingkat Pendidikan.

Sumber : Data Primer, 2020.

Berdasarkan gambar di atas dapat dilihat bahwa sebagian besar konsumen yang membeli beras merah dari 70 responden berdasarkan tingkat pendidikan SD sederajat sebanyak 4 orang atau $6 \%$, pada tingkat pendidikan SMP sebanyak 4 orang atau sebesar 6\%, pada tingkat pendidikan SMA sebanyak 49 orang atau sebesar 70\%, sedangkat pada tingkat pendidikan S1 (Perguruan Tinggi) sebanyak 13 orang atau sebesar 18\%.

Dari hasil penelitian pada tingkat pendidikan bahwa konsumen beras merah pada umumnya banyak di konsumsi oleh tingkat pendidikan SMA. Hal tersebut dapat dilihat bahwa mereka mengkonsumsi beras merah karena mereka beranggapan bahwa merah 
mempunyai manfaat yang banyak dan aroma yang wangi.

\section{Karakteristik Responden Berdasarkan Pendapatan Perbulan}

Berdasarkan pendapatan perbulan, responden dalam penelitian ini dibedakan menjadi responden berpendapatan $<\mathrm{Rp}$. 1 juta, Rp. 1-2 juta, Rp. 2-3 juta dan $>$ Rp. 3 juta. Hasil analisis karakteristik responden berdasarkan pendapatan perbulan dapat dilihat pada gambar 5 :

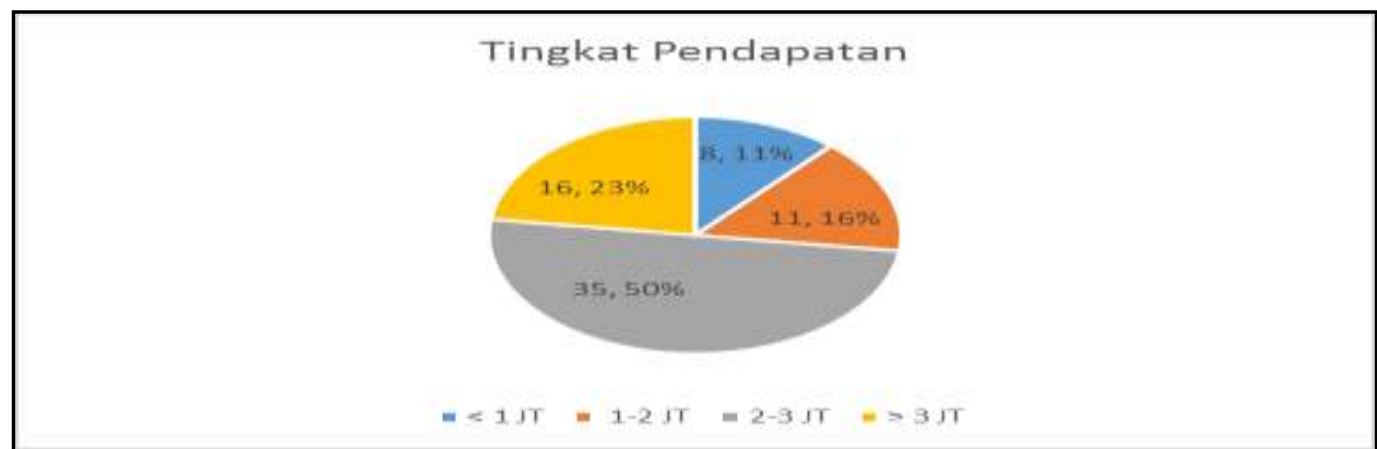

Gambar 5. Karakteristik Responden Berdasarkan Pendapatan Perbulan.

Sumber : Data Primer, 2020.

Berdasarkan pada gambar di atas dapat dilihat bahwa sebagian besar konsumen yang membeli beras dari 70 reponden berdasarkan pendapatan perbulan $<$ Rp. 1 juta sebanyak 8 orang atau sebesar $11 \%$, responden dengan pendapat perbulan anatara Rp. 1-2 juta sebanyak 11 orang atau sebesar 16\%, responden dengan pendapat perbulan anatara Rp. 2-3 juta sebanyak 35 orang atau sebesar $50 \%$, dan responden yang berpendapat perbulan $>$ Rp. 3 juta sebanyak 15 orang atau sebesar $23 \%$.

$$
\text { Pendapatan akan sangat }
$$

berpengaruh pada tingkat konsumsi terutama konsumsi beras merah. Dikarenakan harga beras merah cenderung di atas harga beras pada umumnya sehingga pendapatan akan sangat berpengaruh terhadap konsumsinya.

\section{Pengukuran Instrumen Penelitian}

Instrumen yang digunakan dalam penelitian ini adalah kuesioner. Kuesioner yang diajukan berupa kuesioner tertutup dengan memberikan pernyataan kepada responden,menggunakan skala pengukuran 1 sampai 5 (skala likert) yang teridiri dari : 1. Sangat Tidak Puas (STP), 2. Tidak Puas (TS), 3. Cukup Puas (CP), 4. Puas (S) dan 5. Sangat Puas (SS). Agar tidak terjadi penyimpangan dan bias dalam jawaban dari responden maka perlu dilakukan uji instrumen penelitian berupa uji validitas dan reliabilitas.

\section{Uji Validitas}

Uji validitas digunakan untuk mengetahui kevalidan angket atau kuesioner dalam mengumpulkan data. Uji validitas digunakan dengan rumus korelasi bivariate person dengan alat bantu program SPSS. Item angket dalam uji validitas dikatakan valid jika harga $\mathbf{r}_{\text {hitung }}>$ $\mathrm{r}_{\text {tabel }}$ pada nilai signifikansi 5\%, sebaliknya item dikatakan tidak valid jika harga $r_{\text {hitung }}$ $<r_{\text {tabel }}$ pada nilai signifikansi 5\%. Adapun ringkasan hasil uji validitas sebagaimana data dalam tabel tersebut.

Uji validitas bertujuan untuk mengetahui valid tidaknya suatu data. Data dinyatakan valid apabila $\mathrm{r}$ hitung $>\mathrm{r}$ tabel, dengan mengunakan rumus $\mathrm{df}=\mathrm{n}-\mathrm{k}$ dengan demikian diperoleh $\mathrm{t}$ tabel sebesar $70-2=68=0,235$ (Sarjono dan Julianita, 2011). 
Tabel 2. Uji Validitas Harga (X1).

\begin{tabular}{cccc}
\hline No Item & r tabel $\mathbf{5 \%}(\mathbf{7 0})$ & r hitung & Keterangan \\
\hline 1 & 0,235 & $\mathbf{0 , 7 5 9}$ & Valid \\
2 & 0,235 & $\mathbf{0 , 7 6 9}$ & Valid \\
3 & 0,235 & $\mathbf{0 , 7 6 0}$ & Valid \\
4 & 0,235 & $\mathbf{0 , 6 0 0}$ & Valid \\
\hline
\end{tabular}

Sumber : Hasil Pengolahan Data Primer, 2020.

Tabel 3. Uji Validitas Kualitas Produk (X2).

\begin{tabular}{cccc}
\hline No Item & r tabel $\mathbf{5 \%} \mathbf{( 7 0 )}$ & r hitung & Keterangan \\
\hline 1 & 0,235 & $\mathbf{0 , 6 8 1}$ & Valid \\
2 & 0,235 & $\mathbf{0 , 7 3 7}$ & Valid \\
3 & 0,235 & $\mathbf{0 , 2 6 4}$ & Valid \\
4 & 0,235 & $\mathbf{0 , 7 2 8}$ & Valid \\
5 & 0,235 & $\mathbf{0 , 5 2 8}$ & Valid \\
\hline
\end{tabular}

Sumber : Hasil Pengolahan Data Primer, 2020

Tabel 4. Uji Validitas Kepuasan Konsumen (Y).

\begin{tabular}{cccc}
\hline No Item & r tabel $\mathbf{5 \%}(\mathbf{7 0 )}$ & r hitung & Keterangan \\
\hline 1 & 0,235 & $\mathbf{0 , 8 6 9}$ & Valid \\
2 & 0,235 & $\mathbf{0 , 8 6 0}$ & Valid \\
3 & 0,235 & $\mathbf{0 , 7 1 6}$ & Valid \\
4 & 0,235 & $\mathbf{0 , 6 6 9}$ & Valid \\
\hline
\end{tabular}

Sumber : Hasil Pengolahan Data Primer, 2020.

Berdasarkan tabel di atas dapat dilihat bahwa hasil uji validitas terhadap semua indikator X1, X2 serta Y menunjukkan hasil yang valid atau sah, dengan demikian dapat dilakukan analisis lanjut analisis regresi berganda. Untuk $\mathrm{n}=$ 70 , nilai $\mathrm{r}$ tabel $(\alpha=5 \%)$ adalah 0,235 , dari hasil uji validitas dengan menggunakan SPSS untuk setiap pertanyaan atau indikator pada kuesioner menunjukkan hasil $r$ hitung $>r$ tabel 0,235, sehingga dapat dilakukan bahwa setiap pertanyaan kuesioner sudah valid.

\section{Uji Reliabilitas}

Uji Reliabilitas adalah suatu nilai yang menunjukan konsistensi suatu alat pengukur dalam mengukur gejala yang

Tabel 5. Uji Reliabilitas.

\begin{tabular}{cccc}
\hline Variabel & Cronbach's Alpa Coefficient & Cronbach's Alpa Accaptable & Keterangan \\
\hline X1 & 0,697 & 0,60 & Reliabel \\
X2 & 0,670 & 0,60 & Reliabel \\
Y & 0,784 & 0,60 & Reliabel \\
\hline
\end{tabular}

Sumber : Hasil Pengolahan Data Primer, 2020.

Dari tabel di atas variabel harga (X1) menghasilkan nilai cronbach Alpha 0,697, variabel kualitas produk (X2) 0,670 dan varibel kepuasan konsumen (Y) sama. Uji reliabilitas dari setiap konstruk yang digunakan dalam penelitian ini menggunakan Cronbach's Alpha dengan bantuan ssoftware SPSS 25.0. Cronbach's Alpha yang cukup dapat diterima adalah yang bernilai 0,60 sampai 0,70 atau lebih (Sekaran, 2003). Dasar pengambilan keputusan uji reliabilitas untuk instrumen yang reliabel adalah sebagai berikut :

- Jika Cronbach's coefficient alpha (a) > 0.6 maka cronbach's alpha acceptable (construct reliable) atau pertanyaan dalam kuesioner layak digunakan.

- Jika Cronbach's coefficient alpha (a) < 0.6 maka cronbach's alpha acceptable (construct reliable) atau pertanyaan dalam kuesioner tidak layak digunakan.
0,784. Berdasarkan tabel diatas dapat dilihat bahwa cronbach's alpa coefficient >cronbach's alpa acceptable maka dengan demikian pada tiap-tiap pertanyaan 
maupun tiap-tiap variabel menunjukan hasil kuesioner sudah reliabel.

\section{Tanggapan Responden Terhadap Variabel Harga, Kualitas Produk, dan Kepuasan Konsumen}

Dalam penelitian ini, perlu dikemukan bahwa skor tertinggi dan skor terendah dari indikator - indikator variabel harga, variabel kualitas produk, dan variabel kepuasan konsumen yaitu : 5 x $70=350$, sedangkan untuk skor terendah yaitu : $1 \times 70=70$, skor tersebut akan digunakan untuk mencari bobot pada setiap indikator dari variabel harga, kualitas produk, dan kepuasan konsumen dengan rentang skor 56. Untuk lebih jelasnya, bobot pada indikator -indikator tersebut dapat dilihat pada tabel berikut ini :

Tabel 6. Tanggapan Responden Terhadap (Variabel Harga, X1.1) Harga jual beras merah telah disesuaikan dengan biaya pemasukan dan biaya pengeluaran

\begin{tabular}{lccc}
\hline \multicolumn{1}{c}{ Tanggapan } & Frekuensi (orang) & Persentase (\%) & Skor \\
\hline Sangat Puas & 17 & 24 & 85 \\
Puas & 44 & 63 & 176 \\
Cukup Puas & 4 & 6 & 12 \\
Tidak Puas & 5 & 7 & 10 \\
Sangat Tidak Puas & 0 & 0 & 0 \\
\hline Total Skor & $\mathbf{7 0}$ & $\mathbf{1 0 0}$ & $\mathbf{2 8 3}$ \\
\hline
\end{tabular}

Sumber : Data Kuesioner (Diolah, 2020)

Berdasarkan tabel di atas, maka skor bobot untuk item pertama (X1.1.) pada indikator variabel harga adalah sebagai berikut :

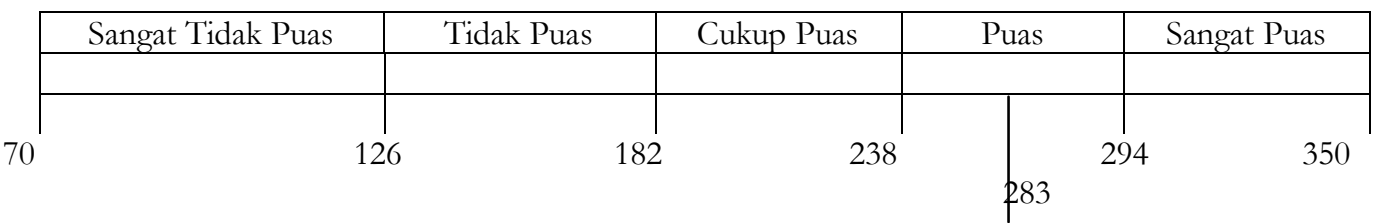

Berdasarkan tabel di atas dapat diketahui bahwa bobot harga jual beras merah sesuai dengan biaya pemasukan dan biaya pengeluaran memiliki skor 283 , hal ini menunjukkan bahwa item indikator harga terhadap kepuasan konsumen sudah puas.

Tabel 7. Tanggapan Responden Terhadap (Variabel Harga, X1.2) Harga beras merah terjangkau.

\begin{tabular}{lccc}
\hline \multicolumn{1}{c}{ Tanggapan } & Frekuensi (orang) & Persentase (\%) & Skor \\
\hline Sangat Puas & 28 & 40 & 140 \\
Puas & 34 & 49 & 136 \\
Cukup Puas & 4 & 6 & 12 \\
Tidak Puas & 3 & 4 & 6 \\
Sangat Tidak Puas & 1 & 1 & 1 \\
\hline \multicolumn{1}{c}{ Total Skor } & $\mathbf{7 0}$ & $\mathbf{1 0 0}$ & $\mathbf{2 9 5}$ \\
\hline
\end{tabular}

Sumber : Data Kuesioner (Diolah, 2020).

Berdasarkan tabel di atas, maka skor bobot untuk item kedua (X1.2.) pada

indikator variabel harga adalah sebagai berikut :

\begin{tabular}{|l|r|r|r|r|r|}
\hline Sangat Tidak Puas & Tidak Puas & Cukup Puas & Puas & \multicolumn{2}{|c|}{ Sangat Puas } \\
\hline & & & & & \\
\hline 70 & & 182 & 238 & 294 & 350
\end{tabular}

Berdasarkan tabel di atas dapat diketahui bahwa bobot harga beras merah terjangkau memiliki skor 295, hal ini menunjukkan bahwa item keterjangkauan konsumen dalam membeli beras merah sangat puas. 
Tabel 8. Tanggapan Responden Terhadap (Variabel Harga, X1.3) Konsumen diberikan hak untuk menawar harga beras.

\begin{tabular}{lccc}
\hline \multicolumn{1}{c}{ Tanggapan } & Frekuensi (orang) & Persentase (\%) & Skor \\
\hline Sangat Puas & 45 & 64 & 225 \\
Puas & 22 & 31 & 88 \\
Cukup Puas & 0 & 0 & 0 \\
Tidak Puas & 3 & 4 & 6 \\
Sangat Tidak Puas & 0 & 0 & 0 \\
\hline Total Skor & $\mathbf{7 0}$ & $\mathbf{1 0 0}$ & $\mathbf{3 1 9}$ \\
\hline
\end{tabular}

Sumber : Data Kuesioner (Diolah, 2020).

Berdasarkan tabel di atas, maka skor bobot untuk item (X1.3.) pada

indikator variabel harga adalah sebagai berikut :

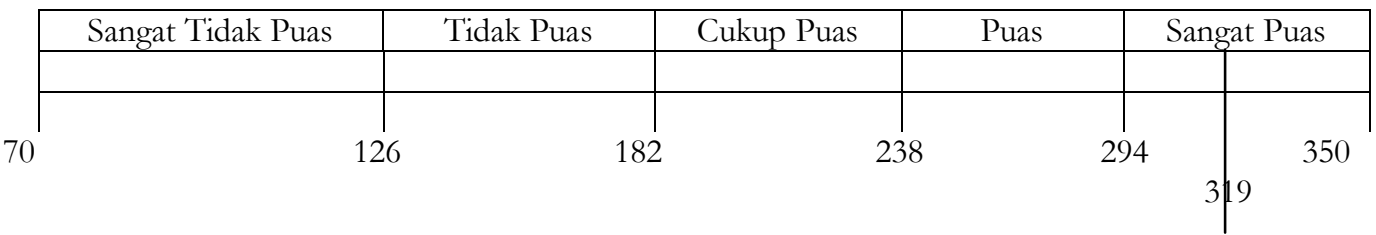

Berdasarkan tabel di atas dapat diketahui bahwa bobot konsumen diberikan hak untuk menawar harga beras memiliki skor 319, hal ini menunjukkan bahwa item indikator harga terhadap kepuasan konsumen sudah sangat puas, karena konsumen tidak dibatasi untuk menawar harga beras merah.

Tabel 9.Tanggapan Responden Terhadap (Variabel Harga, X1.4) Produsen memberikan potongan harga beras merah kepada konsumen.

\begin{tabular}{lccc}
\hline \multicolumn{1}{c}{ Tanggapan } & Frekuensi (orang) & Persentase (\%) & Skor \\
\hline Sangat Puas & 43 & 61 & 215 \\
Puas & 25 & 36 & 100 \\
Cukup Puas & 2 & 3 & 6 \\
Tidak Puas & 0 & 0 & 0 \\
Sangat Tidak Puas & 0 & 0 & 0 \\
\hline Total Skor & $\mathbf{7 0}$ & $\mathbf{1 0 0}$ & $\mathbf{3 2 1}$ \\
\hline
\end{tabular}

Sumber : Data Kuesioner (Diolah, 2020).

Berdasarkan tabel di atas, maka skor bobot untuk item (X1.4.) pada

indikator variabel harga adalah sebagai berikut :

\begin{tabular}{|l|r|r|r|r|r|}
\hline Sangat Tidak Puas & Tidak Puas & Cukup Puas & \multicolumn{2}{c|}{ Puas } & \multicolumn{2}{|c|}{ Sangat Puas } \\
\hline & & & & \multicolumn{2}{|l|}{} \\
\hline 70 & 126 & 238 & 294 & 350 \\
\hline
\end{tabular}

Berdasarkan tabel di atas dapat diketahui bahwa bobot produsen memberikan potongan harga beras merah kepada konsumen memiliki skor 321, hal ini menunjukkan bahwa item indikator harga terhadap kepuasan konsumen sudah sangat puas, karena produsen akan memberikan diskon potongan harga apabila konsumen membeli dengan kuantitas yang cukup banyak.

Berdasarkan uraian tabel tanggapan responden di atas, item indikator dari variabel harga terhadap kepuasan konsumen dirangkum pada tabel berikut: 
Tabel 10.Rangkuman Tanggapan Responden Terhadap Variabel Harga. $(\mathrm{n}=70$ ).

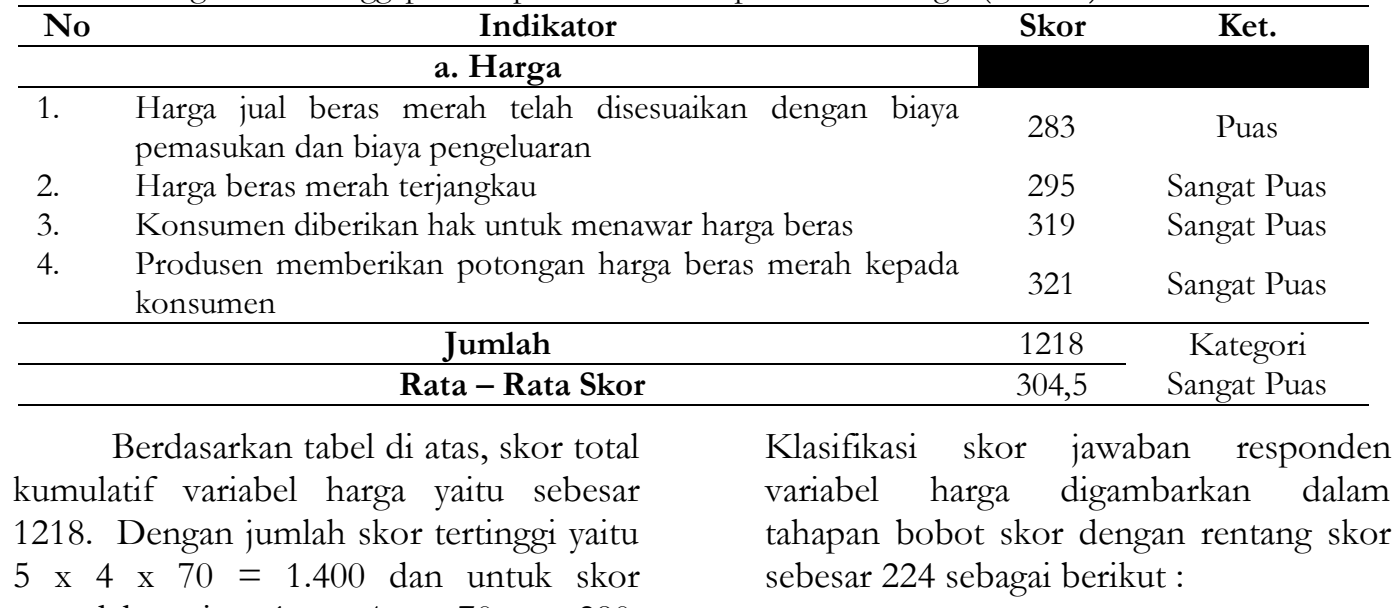
terendah yaitu 1 × 4 × $70=280$.

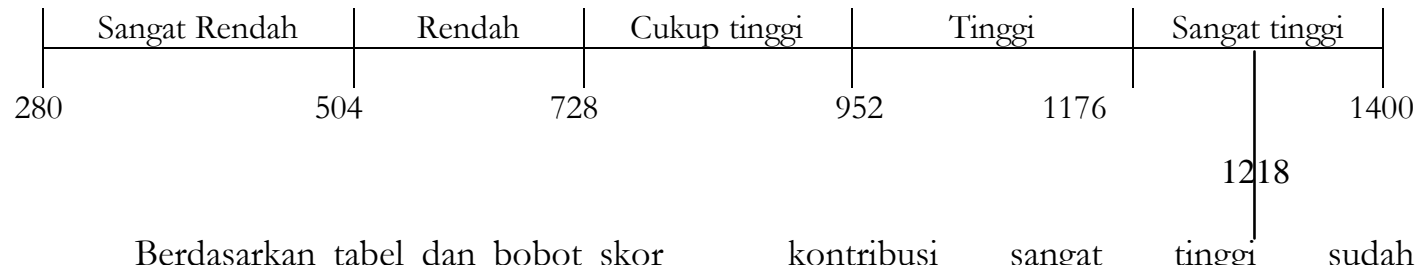

Berdasarkan tabel dan bobot skor diatas, menunjukkan bahwa variabel harga berkontribusi sangat tinggi untuk mempengaruhi kepuasan konsumen di CV.Pure Cianjur, karena dengan kontribusi sangat tinggi sudah mencerminkan bahwa konsumen merasa sangat puas dengan harga yang di tawarkan/ diberikan oleh perusahaan.

Tabel 11. Tanggapan Responden Terhadap (Variabel Kualitas Produk, X2.1) Beras merah memiliki aroma yang khas

\begin{tabular}{lccc}
\hline \multicolumn{1}{c}{ Tanggapan } & Frekuensi (orang) & Persentase (\%) & Skor \\
\hline Sangat Puas & 26 & 37 & 130 \\
Puas & 38 & 54 & 152 \\
Cukup Puas & 2 & 3 & 6 \\
Tidak Puas & 4 & 6 & 8 \\
Sangat Tidak Puas & 0 & 0 & 0 \\
\hline Total Skor & $\mathbf{7 0}$ & $\mathbf{1 0 0}$ & $\mathbf{2 9 6}$ \\
\hline
\end{tabular}

Sumber : Data Kuesioner (Diolah, 2020).

Berdasarkan tabel di atas, maka skor bobot untuk item (X2.1) pada indikator variabel kualitas adalah sebagai berikut :

\begin{tabular}{|l|r|r|r|r|}
\hline Sangat Tidak Puas & Tidak Puas & Cukup Puas & Puas & Sangat Puas \\
\hline & & & & \\
\hline 70 & 126 & 182 & 238 & 294 \\
3
\end{tabular}

Berdasarkan tabel di atas dapat diketahui bahwa bobot beras merah memiliki aroma yang khas memiliki skor 296, hal ini menunjukkan bahwa item indikator kualitas produk terhadap kepuasan konsumen sudah sangat puas, karena beras merah identik dengan aromanya yang khas. 
Tabel 12. Tanggapan Responden Terhadap (Variabel Kualitas Produk, X2.2) Beras merah memiliki warna merah terang.

\begin{tabular}{lccc}
\hline \multicolumn{1}{c}{ Tanggapan } & Frekuensi (orang) & Persentase (\%) & Skor \\
\hline Sangat Puas & 20 & 29 & 100 \\
Puas & 37 & 53 & 148 \\
Cukup Puas & 3 & 4 & 9 \\
Tidak Puas & 10 & 14 & 20 \\
Sangat Tidak Puas & 0 & 0 & 0 \\
\hline Total Skor & $\mathbf{7 0}$ & $\mathbf{1 0 0}$ & $\mathbf{2 7 7}$ \\
\hline
\end{tabular}

Sumber : Data Kuesioner (Diolah, 2020)

Berdasarkan tabel di atas, maka skor bobot untuk item (X2.2) pada

indikator variabel kualitas adalah sebagai berikut :

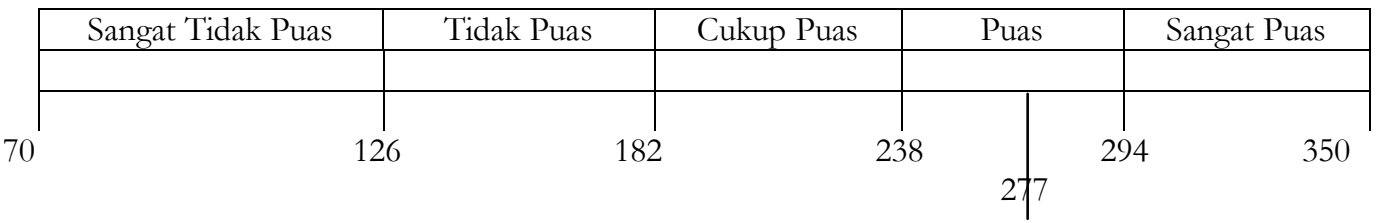

Berdasarkan tabel di atas dapat diketahui bahwa bobot beras merah memiliki warna merah terang yang khas memiliki skor 277, hal ini menunjukkan bahwa item indikator kualitas produk terhadap kepuasan konsumen sudah puas, karena beras merah memiliki bulir beras yang terang.

Tabel 13. Tanggapan Responden Terhadap (Variabel Kualitas Produk, X2.3) Kandungan gizi yang dimiliki beras merah tinggi.

\begin{tabular}{lccc}
\hline \multicolumn{1}{c}{ Tanggapan } & Frekuensi (orang) & Persentase (\%) & Skor \\
\hline Sangat Puas & 53 & 76 & 265 \\
Puas & 17 & 24 & 68 \\
Cukup Puas & 0 & 0 & 0 \\
Tidak Puas & 0 & 0 & 0 \\
Sangat Tidak Puas & 0 & 0 & 0 \\
\hline Total Skor & $\mathbf{7 0}$ & $\mathbf{1 0 0}$ & $\mathbf{3 3 3}$ \\
\hline
\end{tabular}

Sumber : Data Kuesioner (Diolah, 2020).

Berdasarkan tabel di atas, maka skor bobot untuk item (X2.3) pada

indikator variabel kualitas adalah sebagai berikut :

\begin{tabular}{|l|r|r|r|r|r|}
\hline Sangat Tidak Puas & Tidak Puas & Cukup Puas & \multicolumn{2}{c|}{ Puas } & \multicolumn{2}{|c|}{ Sangat Puas } \\
\hline & & & & \multicolumn{2}{|c|}{} \\
\hline 70 & 182 & 238 & 294 & 350 \\
\hline
\end{tabular}

Berdasarkan tabel di atas dapat diketahui bahwa bobot kandungan gizi yang dimiliki beras merah tinggi memiliki skor 333, hal ini menunjukkan bahwa item indikator kualitas produk terhadap kepuasan konsumen sudah sangat puas, karena beras merah memiliki kandungan gizi paling tinggi dibandingkan dengan jenis beras lainnya. 
Tabel 14. Tanggapan Responden Terhadap (Variabel Kualitas Produk, X2.4) Bentuk atau bulir beras merah tidak mudah patah.

\begin{tabular}{lccc}
\hline \multicolumn{1}{c}{ Tanggapan } & Frekuensi (orang) & Persentase (\%) & Skor \\
\hline Sangat Puas & 19 & 27 & 95 \\
Puas & 37 & 53 & 148 \\
Cukup Puas & 7 & 10 & 21 \\
Tidak Puas & 7 & 10 & 14 \\
Sangat Tidak Puas & 0 & 0 & 0 \\
\hline Total Skor & $\mathbf{7 0}$ & $\mathbf{1 0 0}$ & $\mathbf{2 7 8}$ \\
\hline
\end{tabular}

Sumber : Data Kuesioner (Diolah, 2020).

Berdasarkan tabel di atas, maka indikator variabel kualitas adalah sebagai skor bobot untuk item (X2.4) pada berikut:

\begin{tabular}{|l|r|r|r|r|r|}
\hline Sangat Tidak Puas & Tidak Puas & Cukup Puas & Puas & Sangat Puas \\
\hline & & & & \\
\hline 70 & 126 & 182 & 238 & & \\
278 & & & \\
\hline
\end{tabular}

Berdasarkan tabel di atas dapat diketahui bahwa bobot bulir beras merah tidak mudah patah memiliki skor 278 , hal ini menunjukkan bahwa item indikator kualitas produk terhadap kepuasan konsumen sudah puas, karena beras merah memiliki bulir yang cukup kuat sehingga tidak mudah patah.

Tabel 15. Tanggapan Responden Terhadap (Variabel Kualitas Produk, X2.5) Beras merah memiliki tekstur nasi pulen setelah dimasak.

\begin{tabular}{lccc}
\hline \multicolumn{1}{c}{ Tanggapan } & Frekuensi (orang) & Persentase (\%) & Skor \\
\hline Sangat Puas & 44 & 63 & 220 \\
Puas & 24 & 34 & 96 \\
Cukup Puas & 1 & 1 & 3 \\
Tidak Puas & 1 & 1 & 2 \\
Sangat Tidak Puas & 0 & 0 & 0 \\
\hline Total Skor & $\mathbf{7 0}$ & $\mathbf{1 0 0}$ & $\mathbf{3 2 1}$ \\
\hline
\end{tabular}

Sumber : Data Kuesioner (Diolah, 2020).

Berdasarkan table di atas, maka indikator variabel kualitas adalah sebagai skor bobot untuk item (X2.5) pada berikut:

\begin{tabular}{|l|r|r|r|r|r|}
\hline Sangat Tidak Puas & Tidak Puas & Cukup Puas & Puas & \multicolumn{2}{c|}{ Sangat Puas } \\
\hline & & & & \multicolumn{2}{|c|}{} \\
\hline 70 & 126 & 182 & 238 & 294 & \\
3250
\end{tabular}

Berdasarkan tabel di atas dapat diketahui bahwa bobot beras merah memiliki tekstur pulen setelah dimasak skor 321, hal ini menunjukkan bahwa item indikator kualitas produk terhadap kepuasan konsumen sudah sangat puas, karena beras merah memiliki tekstur yang pulen dan banyak disukai oleh konsumen. 
Tabel 16. Rangkuman Tanggapan Responden Terhadap Variabel kualitas beras merah. $(\mathrm{n}=70)$.

\begin{tabular}{clcl}
\hline & \multicolumn{1}{c}{ Indikator } & Skor & Ket. \\
\cline { 2 - 4 } No & \multicolumn{1}{c}{ b. Kualitas Beras Merah } & 296 & Sangat Puas \\
\hline 1. & Beras merah memiliki aroma yang khas & 277 & Puas \\
2. & Beras merah memiliki warna merah terang & 333 & Sangat Puas \\
3. & Kandungan gizi yang dimiliki beras merah merah tinggi & 278 & Puas \\
4. & Bentuk/bulir beras merah utuh tidak patah & 321 & Sangat Puas \\
5. & Beras merah memiliki tekstur nasi pulen setelah di masak & 1505 & Kategori Sangat \\
\hline & Rumlah & 301 & Puas \\
\hline
\end{tabular}

Berdasarkan tabel di atas, skor total kumulatif variabel harga yaitu sebesar 1505. Dengan jumlah skor tertinggi yaitu $5 \times 5 \times 70=1.750$ dan untuk skor terendah yaitu $1 \times 5 \times 70=350$.
Klasifikasi skor jawaban responden variabel kualitas beras merah digambarkan dalam tahapan bobot skor dengan rentang skor sebesar 280 sebagai berikut :

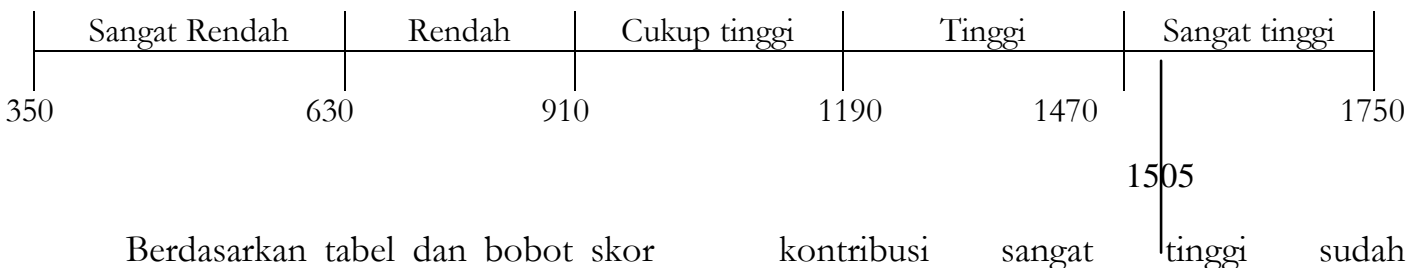
di atas, menunjukkan bahwa variabel kualitas berkontribusi sangat tinggi untuk mempengaruhi kepuasan konsumen di CV. Pure Cianjur, karena dengan mencerminkan bahwa konsumen merasa sangat puas dengan kualitas produk yang ada di perusahaan.

Tabel 17. Tanggapan Responden Terhadap (Variabel Kepuasan Konsumen, Y.1) Kualitas beras merah sesuai dengan harapan konsumen.

\begin{tabular}{lccc}
\hline \multicolumn{1}{c}{ Tanggapan } & Frekuensi (orang) & Persentase (\%) & Skor \\
\hline Sangat Puas & 30 & 43 & 150 \\
Puas & 32 & 46 & 128 \\
Cukup Puas & 3 & 4 & 9 \\
Tidak Puas & 5 & 7 & 10 \\
Sangat Tidak Puas & 0 & 0 & 0 \\
\hline Total Skor & $\mathbf{7 0}$ & $\mathbf{1 0 0}$ & $\mathbf{2 9 7}$ \\
\hline
\end{tabular}

Sumber : Data Kuesioner (Diolah, 2020).

Berdasarkan table di atas, maka skor bobot untuk item (Y.1) pada indikator variabel kepuasan konsumen adalah sebagai berikut :

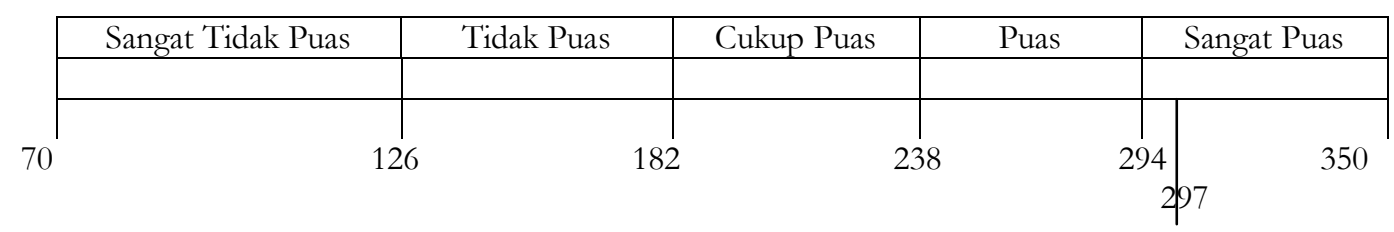

Berdasarkan tabel di atas dapat diketahui bahwa bobot kualitas beras merah sesuai dengan harapan konsumen memiliki skor 297, hal ini menunjukkan bahwa item indikator kepuasan konsumen sudah sangat puas, karena konsumen beras merasa puas dengan beras merah yang dihasilkan. 
Tabel 18.Tanggapan Responden Terhadap (Variabel Kepuasan Konsumen, Y.2) Harga yang ditawarkan kepada konsumen sesuai dengan harapan.

\begin{tabular}{lccc}
\hline \multicolumn{1}{c}{ Tanggapan } & Frekuensi (orang) & Persentase (\%) & Skor \\
\hline Sangat Puas & 23 & 33 & 115 \\
Puas & 37 & 53 & 148 \\
Cukup Puas & 5 & 7 & 15 \\
Tidak Puas & 5 & 7 & 10 \\
Sangat Tidak Puas & 0 & 0 & 0 \\
\hline Total Skor & $\mathbf{7 0}$ & $\mathbf{1 0 0}$ & $\mathbf{2 8 8}$ \\
\hline
\end{tabular}

Sumber : Data Kuesioner (Diolah, 2020).

Berdasarkan table di atas, maka indikator variabel kepuasan konsumen skor bobot untuk item (Y.2) pada adalah sebagai berikut :

\begin{tabular}{|l|r|r|r|r|r|}
\hline Sangat Tidak Puas & Tidak Puas & Cukup Puas & Puas & Sangat Puas \\
\hline & & & & & \\
\hline 70 & 126 & 182 & 238 & & \\
294 & 350 \\
\hline
\end{tabular}

Berdasarkan tabel di atas dapat diketahui bahwa bobot harga yang ditawarkan kepada konsumen sesuai dengan harapan memiliki skor 288, hal ini menunjukkan bahwa item indikator kepuasan konsumen sudah puas, karena harga beras meras sebanding dengan kualitas yang diinginkan konsumen.

Tabel 19. Tanggapan Responden Terhadap (Variabel Kepuasan Konsumen, Y.3) Tetap membeli dan mengkonsumsi beras merah karena kualitasnya sesuai dengan manfaat.

\begin{tabular}{lccc}
\hline \multicolumn{1}{c}{ Tanggapan } & Frekuensi (orang) & Persentase (\%) & Skor \\
\hline Sangat Puas & 29 & 41 & 145 \\
Puas & 40 & 57 & 160 \\
Cukup Puas & 1 & 1 & 3 \\
Tidak Puas & 0 & 0 & 0 \\
Sangat Tidak Puas & 0 & 0 & 0 \\
\hline Total Skor & $\mathbf{7 0}$ & $\mathbf{1 0 0}$ & $\mathbf{3 0 8}$ \\
\hline
\end{tabular}

Sumber : Data Kuesioner (Diolah, 2020).

Berdasarkan tabel di atas, maka skor bobot untuk item (Y.3) pada

indikator variabel kepuasan konsumen adalah sebagai berikut :

\begin{tabular}{|l|r|r|r|r|r|}
\hline Sangat Tidak Puas & Tidak Puas & Cukup Puas & \multicolumn{2}{c|}{ Puas } & \multicolumn{2}{|c|}{ Sangat Puas } \\
\hline & & & & \multicolumn{2}{|c|}{} \\
\hline 70 & 126 & 182 & 238 & 294 & 350 \\
\hline
\end{tabular}

Berdasarkan tabel di atas dapat diketahui bahwa bobot tetap membeli dan mengkonsumsi beras merah karena kualitasnya sesuai dengan manfaat memiliki skor 308, hal ini menunjukkan bahwa item indikator kepuasan konsumen sudah sangat puas, karena konsumen dalam membeli beras merah sesuai dengan kualitas yang diinginkan. 
Tabel 20. Tanggapan Responden Terhadap (Variabel Kepuasan Konsumen, Y.4) Tetap membeli dan mengkonsumsi beras merah karena harganya sesuai dengan manfaat.

\begin{tabular}{lccc}
\hline \multicolumn{1}{c}{ Tanggapan } & Frekuensi (orang) & Persentase (\%) & Skor \\
\hline Sangat Puas & 29 & 41 & 145 \\
Puas & 39 & 56 & 156 \\
Cukup Puas & 1 & 1 & 3 \\
Tidak Puas & 0 & 0 & 0 \\
Sangat Tidak Puas & 1 & 1 & 1 \\
\hline Total Skor & $\mathbf{7 0}$ & $\mathbf{1 0 0}$ & $\mathbf{3 0 5}$ \\
\hline
\end{tabular}

Sumber : Data Kuesioner (Diolah, 2020).

Berdasarkan tabel di atas, maka skor bobot untuk item (Y.4) pada indikator variabel kepuasan konsumen adalah sebagai berikut :

\begin{tabular}{|l|r|r|r|r|r|}
\hline Sangat Tidak Puas & Tidak Puas & Cukup Puas & Puas & \multicolumn{2}{c|}{ Sangat Puas } \\
\hline & & & & \\
\hline 70 & 126 & 182 & 238 & 294 & \\
\hline & & & & 350
\end{tabular}

Berdasarkan tabel di atas dapat diketahui bahwa bobot tetap membeli dan mengkonsumsi beras merah karena harganya sesuai dengan manfaat memiliki skor 305, hal ini menunjukkan bahwa item indikator kepuasan konsumen sudah sangat puas, karena konsumen dalam membeli beras merah sesuai dengan harga yang diinginkan.

Tabel 21.Rangkuman Tanggapan Responden Terhadap Variabel Kepuasan Konsumen. ( $\mathrm{n}=70$ ).

\begin{tabular}{|c|c|c|c|}
\hline & Indikator & Skor & Ket. \\
\hline No & c. Kepuasan Konsumen & & \\
\hline 1. & Kualitas beras merah sesuai dengan harapan konsumen & 297 & Sangat Puas \\
\hline 2. & $\begin{array}{l}\text { Harga yang ditawarkan kepada konsumen sesuai dengan } \\
\text { harapan }\end{array}$ & 288 & Puas \\
\hline 3. & $\begin{array}{l}\text { Tetap membeli dan mengkonsumsi beras merah karena } \\
\text { kualitasnya sesuai dengan manfaat }\end{array}$ & 308 & Sangat Puas \\
\hline 4. & $\begin{array}{l}\text { Tetap membeli dan mengkonsumsi beras merah karena } \\
\text { harganya sesuai dengan manfaat }\end{array}$ & 305 & Sangat Puas \\
\hline & Jumlah & 1198 & Kategori Sangat \\
\hline & Rata - Rata & 299,5 & Puas \\
\hline
\end{tabular}

Berdasarkan di atas, skor total kumulatif variabel harga yaitu sebesar 1198. Dengan jumlah skor tertinggi yaitu $5 \times 4 \times 70=1.400$ dan untuk skor terendah yaitu $1 \times 4 \times 70=280$.
Klasifikasi skor jawaban responden variabel kepuasan konsumen digambarkan dalam tahapan bobot skor dengan rentang skor sebesar 224 sebagai berikut :

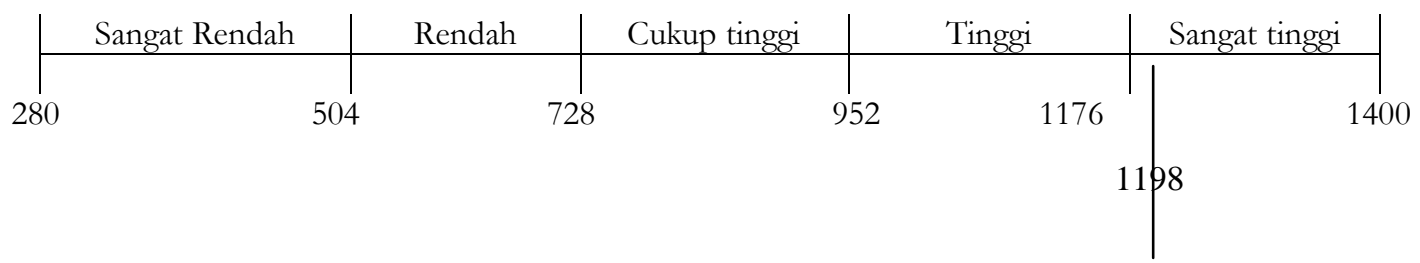

Berdasarkan tabel dan bobot skor di atas, menunjukkan bahwa variabel kepuasan konsumen yang ada di perusahaan berkontribusi sangat tinggi untuk memuaskan konsumen, namun ada beberapa hal yang harus diperhatikan perusahaan agar konsumen tetap merasa puas dengan apa yang diberikan oleh perusahaan yaitu CV. Pure harus memberikan kualitas beras merah dengan warna yang terang bagus dan juga CV.Pure harus memberikan kualitas beras 
merah dengan bentuk/bulir beras yang utuh tidak patah, karena berdasarkan informasi yang didapat dari beberapa responden, mereka pernah menemukan kualitas beras merah tidak sesuai dengan yang diharapkan oleh mereka.
Berdasarkan tabel tanggapan responden di atas, item indikator dari variabel harga, kualitas produk dan kepuasan konsumen dirangkum pada tabel berikut:

Tabel 22.Rangkuman Tanggapan Responden Terhadap Variabel Harga, Kualitas Produk dan Kepuasan Konsumen. ( $\mathrm{n}=70)$.

\begin{tabular}{|c|c|c|c|}
\hline No. & Indikator & Skor & Ket. \\
\hline \multicolumn{4}{|c|}{ a. Harga } \\
\hline 1. & $\begin{array}{l}\text { Harga jual beras merah telah disesuaikan dengan biaya } \\
\text { pemasukan dan biaya pengeluaran }\end{array}$ & 283 & Puas \\
\hline 2. & Harga beras merah terjangkau & 295 & Sangat Puas \\
\hline 3. & Konsumen diberikan hak untuk menawar harga beras & 319 & Sangat Puas \\
\hline 4. & $\begin{array}{l}\text { Produsen memberikan potongan harga beras merah kepada } \\
\text { konsumen }\end{array}$ & 321 & Sangat Puas \\
\hline \multicolumn{4}{|c|}{ b. Kualitas Produk } \\
\hline 5. & Beras merah memiliki aroma yang khas & 296 & Sangat Puas \\
\hline 6. & Beras merah memiliki warna merah terang & 277 & Puas \\
\hline 7. & Kandungan gizi yang dimiliki beras merah tinggi & 333 & Sangat Puas \\
\hline 8. & Bentuk atau bulir beras merah untuk tidak patah & 278 & Puas \\
\hline 9. & Beras merah memiliki tekstur nasi pulen setelah dimasak & 321 & Sangat Puas \\
\hline \multicolumn{4}{|c|}{ c. Kepuasan Konsumen } \\
\hline 10. & Kualitas beras merah sesuai dengan harapan konsumen & 297 & Sangat Puas \\
\hline 11. & Harga yang ditawarkan kepada konsumen sesuai dengan harapan & 288 & Puas \\
\hline 12. & $\begin{array}{l}\text { Tetap membeli dan mengkonsumsi beras merah karena } \\
\text { kualitasnya sesuai dengan manfaat }\end{array}$ & 308 & Sangat Puas \\
\hline 13 & $\begin{array}{l}\text { Tetap membeli dan mengkonsumsi beras merah karena harganya } \\
\text { sesuai dengan manfaat }\end{array}$ & 305 & Sangat Puas \\
\hline \multicolumn{2}{|r|}{ Jumlah } & 3921 & $\begin{array}{c}\text { Kategori } \\
\text { Sangat Puas }\end{array}$ \\
\hline & Rata - Rata Skor & 301,61 & \\
\hline
\end{tabular}

Sumber : Hasil Data Kuesioner (Diolah, 2020.

Berdasarkan tabel di atas, skor total kumulatif variabel harga, kualitas produk dan kepuasan konsumen yaitu sebesar 3921. Dengan jumlah skor tertinggi yaitu $5 \times 13 \times 70=4550$, dan untuk skor terendah yaitu $1 \times 13$ × $70=910$.
Klasifikasi skor jawaban responden variabel harga, kualitas beras merah, dan kepuasan konsumen digambarkan dalam tahapan bobot skor dengan rentang skor sebesar 728 sebagai berikut :

\begin{tabular}{|l|l|l|l|l|r|}
\hline Sangat Rendah & Rendah & Cukup tinggi & Tinggi & \multicolumn{2}{c|}{ Sangat tinggi } \\
\hline 910 & & 2366 & 3094 & 3822 & \\
4
\end{tabular}

Berdasarkan tabel dan bobot skor di atas, menunjukkan bahwa variabel kualitas berkontribusi sangat tinggi untuk mempengaruhi kepuasan konsumen, namun ada beberapa hal yang harus diperhatikan perusahaan agar konsumen tetap merasa puas dengan apa yang diberikan oleh perusahaan yditu dengan memberikan harga yang ditawarkan kepada konsumen sesuai dengan harapan mereka dan juga CV.Pure selalu mempertimbangkan masukan dari konsumen. 
Analisis Data dan Pembahasan

Analisis Data

a. Uji Signifikansi Secara Parsial ( Uji t)

Jika nilai signifikansi $<0,05$ atau $\mathrm{t}$ hitung $>\mathrm{t}$ tabel maka terdapat pengaruh variabel $\mathrm{X}$ terhadap $\mathrm{Y}$ dan nilai signifikansi $>0,05$ atau $\mathrm{t}$ hitung $<\mathrm{t}$ tabel maka tidak terdapat pengaruh variabel $\mathrm{X}$ terhadap Y. Adapun rumus untuk mencari t tabel sebagai berikut :

$\mathrm{t}$ tabel $=\mathrm{t}(\mathrm{a} / 2):(\mathrm{n}-\mathrm{k}-1)=(0,05 / 2)$ : $(70-2-1=67)=1.996$

Tabel 23. Nilai Koefisien.

\begin{tabular}{|c|c|c|c|c|c|c|}
\hline \multicolumn{7}{|c|}{ Coefficients $^{a}$} \\
\hline \multirow{2}{*}{\multicolumn{2}{|c|}{ Model }} & Unstandardize & Coefficients & Standardized Coefficients & \multirow[b]{2}{*}{$\mathrm{T}$} & \multirow[b]{2}{*}{ Sig. } \\
\hline & & $\mathrm{B}$ & Std. Error & Beta & & \\
\hline 1 & (Constant) & 7.884 & 1.534 & & 5.139 & .000 \\
\hline & X1_Harga & .260 & .096 & .311 & 2.698 & .009 \\
\hline & X2_Kualitas Produk & .245 & .073 & .387 & 3.357 & .001 \\
\hline
\end{tabular}

Sumber: Pengolahan Primer, 2020.

Persamaan Regresi Linier Berganda :Y

$=7.884+0.260 \mathrm{X} 1+0.245 \mathrm{X} 2$

- Pengaruh Harga (X1) terhadap Kepuasan Konsumen (Y)

Untuk melihat pengaruh Harga (X1) terhadap kepuasan konsumen dapat dilakukan dengan analisis sebagai berikut :

Berdasarkan tabel di atas, diperoleh bahwa nilai $t_{\text {hitung }}>t_{\text {tabel }}$ yaitu $2.698>1.996$, nilai signifikansi $0,009<0,05$. Dengan demikian ada pengaruh yang signifikan dari variabel harga (X1) terhadap kepuasan konsumen.

- Pengaruh Kualitas Produk terhadap Kepuasan Konsumen

Untuk melihat pengaruh kualitas produk (X2) terhadap kepuasan konsumen dapat dilakukan dengan analisis sebagai berikut:

Berdasarkan tabel diatas, diperoleh bahwa nilai $t_{\text {hitung }}>t_{\text {tabel }}$ yaitu $3.357>1.996$, nilai signifikansi
$0,001<0,05$. Dengan demikian ada pengaruh yang signifikan dari variabel kualitas produk (X2) terhadap kepuasan konsumen.

\section{b. Uji Signifikansi Secara Simultan} (Uji F)

Uji F merupakan uji secara bersama-sama untuk menguji signifikansi pengaruh variabel harga (X1) dan kualitas produk (X2) secara bersama-sama terhadap kepuasan konsumen (Y). Uji F dilakukan dengan membandingkan $\mathrm{F}_{\text {hitung }}$ dengan $\mathrm{F}_{\text {tabel }}$.

Jika nilai signifikansi $<0,05$ atau $\mathrm{F}_{\text {hitung }}>\mathrm{F}_{\text {tabel }}$ maka terdapat pengaruh variabel $\mathrm{X}$ secara simultan terhadap $\mathrm{Y}$ dan nilai signifikansi $>0,05$ atau $F_{\text {hitung }}$ $<\mathrm{F}_{\text {tabel }}$ maka tidak terdapat pengaruh variabel $\mathrm{x}$ secara simultan terhadap $\mathrm{Y}$. Adapun rumus untuk mencari f tabel sebagai berikut:

$\mathrm{F}$ tabel $=\mathrm{F}(\mathrm{k}):(\mathrm{n}-\mathrm{k})=(2):(70-2$ $=68)=\mathbf{3 . 1 3}$

Tabel 24. Uji F.

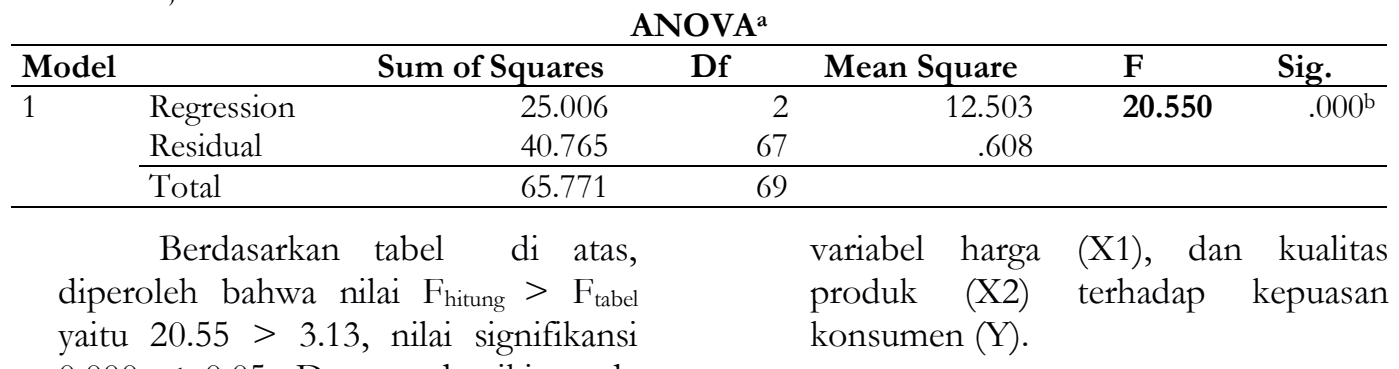

$0,000<0,05$. Dengan demikian ada pengaruh secara simultan atau secara bersama-sama serta signifikan dari 
c. Uji Koefisien Determinasi $\left(\mathbf{R}^{2}\right)$

Analisis determinasi dalam regresi linier berganda digunakan untuk mengetahui persentase sumbangan pengaruh variabel independen secara bersama-sama terhadap variabel dependen (Y). Koefisien ini menunjukan seberapa besar persentase variasi variabel dependen. $\mathrm{R}^{2}$ sama dengan 0 , maka tidak ada sedikitpun persentase sumbangan pengaruh yang diberikan variabel independen terhadap variabel dependen, atau variasi variabel independen yang digunakan dalam model tidak menjelaskan sedikitpun variasi variabel dependen.

Tabel 25. Determinasi.

Model Summary

\begin{tabular}{lrrrr}
\hline Model & R & R Square & Adjusted R Square & Std. Error of the Estimate \\
\hline 1 & $.294^{a}$ & .686 & .059 & 2.19297 \\
\hline Berdasarkan tabel di atas & merah terjangkau (X1.2), konsumen \\
diketahui nilai R Square sebesar 0,686, & diberikan hak untuk menawar harga beras \\
hal tersebut mengandung arti bahwa & (X1.3), produsen memberikan potongan \\
pengaruh variabel X1 dan X2 secara & harga beras merah kepada konsumen \\
simultan atau bersama-sama terhadap & (X1.4). Hal tersebut menunjukan bahwa \\
variabel Y adalah sebesar 68.6\%. & item - item variabel harga mempunyai \\
& nilai yang positif terhadap kepuasan \\
d. Hipotesis Statistik & konsumen dalam membeli beras merah di \\
1). H0 : Ditolak & CV Pure Cianjur.
\end{tabular}

H1 : Diterima, karena nilai $t_{\text {hitung }}>t_{\text {tabel }}$ yaitu $2.698>1.996$, nilai signifikansi $0.009<0,05$

2). H0 : Ditolak

H1 : Diterima, karena nilai $t_{\text {hitung }}>t_{\text {tabel }}$ yaitu $3.357>1.996$, nilai signifikansi $0,001<0,05$ H0 : Ditolak

H1 : Diterima, karena nilai $F_{\text {hitung }}>$ $F_{\text {tabel }}$ yaitu $20.55>3.13$ nilai signifikansi $0.000<0.05$

\section{Pembahasan}

Hasil uji hipotesis digunakan untuk menjawab rumusan masalah untuk mengetahui pengaruh harga, kualitas produk terhadap kepuasan konsumen.

\section{Pengaruh Harga terhadap Kepuasan Konsumen}

Apabila dilihat dari nilai parsial variabel harga memiliki nilai 2.698> 1.966 dengan nilai signifikan 0,009 $<0,05$. Dengan demikian ada pengaruh yang signifikan dari variabel harga (X1) terhadap kepuasan konsumen. Dari variabel harga terdapat empat dimensi yaitu harga jual beras merah telah ditetapkan dengan biaya pemasukan dan biaya pengeluaran (X1.1), harga beras

\section{Pengaruh Kualitas terhadap Kepuasan Konsumen}

Untuk variabel kualitas diperoleh nilai parsial $3.357>1.966$ dengan nilai signifikan $0,001<0,05$. Dengan demikian ada pengaruh yang signifikan dari variabel kualitas produk (X2) terhadap kepuasan konsumen.

Dari variable kualitas terdapat lima dimensi yaitu beras merah memiliki aroma yang khas (X2.1), beras merah memiliki warna merah terang (X2.2), kandungan gizi yang dimiliki beras meras tinggi (X2.3), bentuk/bulir beras merah utuh tidak patah (X2.4), beras merah memiliki tekstur nasi pulen setelah di masak (X2.5). Hal tersebut menunjukan bahwa item item variabel kualitas mempunyai nilai yang positif terhadap kepuasan konsumen dalam membeli beras merah di CV Pure Cianjur.

\section{Pengaruh Harga dan Kualitas Terhadap Kepuasan Konsumen}

Untuk nilai signifikansi secara simultan antara variable harga dan variable kualitas terhadap variable kepuasan konsumen diperoleh nilai 
$20.550>3.01$ dengan nilai signifikansi $0,000<0,05$, artinya faktor harga dan kualitas secara bersama mempengaruhi kepuasan konsumen. Hal ini menjelaskan bahwa 70 orang responden beras merah mempercayai bahwa harga yang tinggi dan kualitas yang baik merupakan hal yang wajar, karena responden merasakan manfaat yang diperoleh setelah mengkonsumsi beras merah. Dengan demikian ada pengaruh secara simultan atau secara bersama-sama serta signifikan dari variabel harga (X1), dan kualitas produk (X2) terhadap kepuasan konsumen $(\mathrm{Y})$.

\section{KESIMPULAN}

Dari hasil penelitian tentang pengaruh harga dan kualitas produk terhadap kepuasan konsumen beras merah di CV Pure Cianjur, dapat disimpulkan sebagai berikut :

1. Harga memiliki pengaruh yang signifikan (nyata) terhadap kepuasan konsumen beras merah di CV Pure Cianjur. Hal ini ditunjukan dengan nilai thitung $>t_{\text {tabel }}$ yaitu $2.698>1.996$, nilai signifikansi $0,009<0,05$. Yang artinya $\mathrm{H} 1$ diterima dan $\mathrm{H} 0$ ditolak.

2. Kualitas produk memiliki pengaruh yang signifikan (nyata) terhadap kepuasan konsumen beras merah di CV Pure Cianjur. Hal ini ditunjukan dengan nilai thitung $>t_{\text {tabel }}$ yaitu3.357 $>$ 1.996, nilai signifikansi $0,001<0,05$. Yang artinya $\mathrm{H} 1$ diterima dan $\mathrm{HO}$ ditolak.

3. Harga dan kualitas produk memiliki pengaruh yang signifikan (nyata) terhadap kepuasan konsumen beras merah di CV Pure Cianjur. Hal ini ditunjukan dengan nilaiF hitung $>\mathrm{F}_{\text {tabel }}$ yaitu $20.55>3.13$, nilai signifikansi $0,000<0,05$. Yang artinya H1diterima dan $\mathrm{HO}$ ditolak.

\section{DAFTAR PUSTAKA}

Ahmad, Usman. 2018. Karakteristik Beras Sosoh Pada Beberapa Tingkat Penyosohan Berdasarkan
Absorbansi. Jurnal Penelitian

Pascapanen Pertanian. 15 (1) : 43-51.

Anwar, Iful. 2015. Pengaruh Harga dan Kualitas Produk Terbadap Keputusan Pembelian. Ilmu dan Riset Manajemen. Vol (4) 12.

Bachtiar. 2011. Analisis Faktor- Faktor Yang Mempengarubi Kepuasan Mahasiswa Dalam Memilib Politeknik. Saunggalih. Aji Purworjo. Dinamika Sosial Ekonomi. Vol (7) 1.

Badan Penelitian dan Pengembangan Pertanian (2005).

Badan Pusat Statistik (BPS). 2012 Faktor Yang Mempengaruhi Volume Impor Beras Di Indonesia

Bella, Rinta. 2019. Tingkat Kepuasan Konsumen Terhadap Beras Bulog Di Desa Lawe Rutung Kecamatan Lawe Bulan Kutacane. Universitas Muhamadiyah Sumatera Utara Medan.

Gita, Yulia Wati. 2018. Analisis Tingkat Kepuasan Konsumen Terhadap Beras Merah Merek Geri Di Kota Padang. Universitas Andalas.

Halim, Abdul. 2007. Urgensi Perlindungan Hak- Hak Konsumen Dalam Transaksi Di E-Commerce. Jurnal Hukum. 14 (2) : 247-270.

Haryanto, Edy. 2013. Kualitas Layanan Fasilitas dan Harga Pengaruhnya Terhadap Kepuasan Pengguna Jasa Layanan Pada Kantor Samsat Manado. Jurnal Emba. 1 (3) :750760.

Hermawan, Edi. Dan Meylani Vita. 2016. Analisis Karakteristik Fisikomia Beras Putih, Beras Merah, Beras Hitam. Jurnal Ilmu Keperawatan. 15 (1) : 79-91.

Ilham, Muhamad Nur. 2012. Analisis Pengendalian Kualitas Produk Dengan Menggunakan Statistical Processing Control (SPC) Pada PT. Bosowa Media Grafika (Tribun Timur). Universitas Hasanudin Makasar.

IRRI, 2013. Quality Kit Manual Version January 2013. Postharvest Unit International Rice Research Institute (IRRI)

Postharvest@irri.org 
Kotler, Philip. 2006. Manajemen Pemasaran, Jilid 1, Terjemahan Hendra Teguh dkk. Jakarta : PT. Prenhalindo.

Nasir, Ahmad. 2017. Tingkat Kepuasan Konsumen Beras Pandanwangi Berdasarkan Pertimbangan Harga dan Kualitas Beras (Studi Kasus : Di Wilayah Pemasaran Kabupaten Cianjur). Skripsi. Jurusan Agribisnis Universitas Suryakancana Cianjur.

Rizky, Muhamad Fakhri. 2014. Pengaruh Promosi dan Harga Terhadap Minat Beli Perumahan Obama PT Nallah Adi Kurnia Medan. Universitas Muhamadiyah Sumatra Utara. Jurnal Manajemen dan Bisnis. 14 (2) : 1693-7619.

Santika, A. dan Rozakurniati. 2010. Teknik Evaluasi Mutu Beras Hitam dan Beras Merah Pada Beberapa Galur Padi Gogo. Buletin Teknik Pertanian. Vol. (15) 1.
Sarjono, Haryadi dan Winda Julianita. 2011. SPSS vs LISREL : Sebuah Pengantar, Aplikasi Untuk Riset. Salemba Empat, Jakarta.

Sekaran, Uma. 2003. Metode Penelitian Untuk Bisnis.

Suardi, Rudi. 2005. Sistem Manajemen Keselamatan Kerja dan Kesehatan Kerja, Jakarta : Penerbit PPM.

Sugiyono, 2015. Metode Penelitian Kuantitatif Kualitatif dan R\&D. Alfabeta, Bandung.

Sugiyono. 2007. Metode Penelitian Kuantitatif Kualitatif dan R\&D. Bandung: Alfabeta.

Sugiyono. 2011. Metode Penelitian Administratif. Bandung: Alfabeta

Sugiyono. 2017. Statistika Untuk Penelitian. Alfabeta. Bandung.

Tjiptono, 2006. Manajemen Jasa. Andi. Yogyakarta.

Widiyanti, Emi dan Cahyadin Malik. 2013. Analisis Rantai Usaha Padi Beras Merah di Kabupaten Boyolali. 